\title{
The Establishment of GABAergic and Glutamatergic Synapses on CA1 Pyramidal Neurons is Sequential and Correlates with the Development of the Apical Dendrite
}

\author{
Roman Tyzio, Alfonso Represa, Isabel Jorquera, Yehezkel Ben-Ari, Henri Gozlan, and Laurent Aniksztejn \\ Institut de Neurobiologie de la Méditérranée, Institut National de la Santé, et de la Recherche Médicale, 13273 Marseille \\ Cedex 09, France
}

\begin{abstract}
We have performed a morphofunctional analysis of CA1 pyramidal neurons at birth to examine the sequence of formation of GABAergic and glutamatergic postsynaptic currents (PSCs) and to determine their relation to the dendritic arborization of pyramidal neurons. We report that at birth pyramidal neurons are heterogeneous. Three stages of development can be identified: (1) the majority of the neurons $(80 \%)$ have small somata, an anlage of apical dendrite, and neither spontaneous nor evoked PSCs; (2) $10 \%$ of the neurons have a small apical dendrite restricted to the stratum radiatum and PSCs mediated only by $\mathrm{GABA}_{\mathrm{A}}$ receptors; and (3) $10 \%$ of the neurons have an apical dendrite that reaches the stratum lacunosum moleculare and PSCs mediated both by $\mathrm{GABA}_{\mathrm{A}}$ and glutamate receptors. These three groups of pyramidal neurons can be differentiated by their capacitance $\left(C_{m}=17.9 \pm 0.8 ; 30.2 \pm 1.6 ; 43.2 \pm 3.0\right.$
\end{abstract}

Several studies suggest that the ionotropic $\mathrm{GABA}_{\mathrm{A}}, \mathrm{NMDA}$, and AMPA receptors display a sequential participation in neuronal excitation during development (Ben-Ari et al., 1989; Hosokawa et al., 1994; Durand et al., 1996; Liu et al., 1996; Garaschuk et al., 1998). In the neonatal hippocampus as in other immature brain structures, GABA, the principal inhibitory transmitter of the adult CNS, provides most of the excitatory drive (Cherubini et al., 1991; Ben-Ari et al., 1997). The shift from the depolarizing to the hyperpolarizing action of GABA is mediated by a change of $\left[\mathrm{Cl}^{-}\right]_{\mathrm{i}}$ (Owens et al., 1996; Rivera et al., 1999) and occurs in the hippocampus at the end of the first postnatal week (Ben-Ari et al., 1989).

The development of the glutamatergic synaptic transmission is characterized by an earlier participation of NMDA than AMPA receptors. Thus, in the hippocampus, electrical stimuli evoke in postnatal day 1 (P1)-P2 pyramidal cells a postsynaptic current blocked only by NMDA receptor antagonists (Ben-Ari et al., 1989; Durand et al., 1996). Because of the voltage-dependent $\mathrm{Mg}^{2+}$ block of NMDA channels, these synapses are "silent" at resting membrane potential. A recent study performed with immunogold electron microscopy provides direct evidence that around birth glutamatergic synapses contain mostly NMDA re-

\footnotetext{
Received June 24, 1999; revised Sept. 1, 1999; accepted Sept. 14, 1999.

Dr. Roman Tyzio is supported by Institut National de la Santé, et de la Recherche Médicale.

Correspondence should be addressed to Laurent Aniksztejn, Institut de Neurobiologie de la Méditérranée, Institut National de la Santé, et de la Recherche Médicale, Unité 29, Parc Scientifique de Luminy, B.P. 13, 13273 Marseille Cedex 09, France. E-mail: anik@inmed.univ-mrs.fr.

Copyright (C) 1999 Society for Neuroscience 0270-6474/99/1910372-11\$05.00/0
}

$\mathrm{pF}$, respectively). At birth, the synaptic markers synapsin-1 and synaptophysin labeling are present in dendritic layers but not in the stratum pyramidale, suggesting that GABAergic peridendritic synapses are established before perisomatic ones. The present observations demonstrate that GABAergic and glutamatergic synapses are established sequentially with GABAergic synapses being established first most likely on the apical dendrites of the principal neurons. We propose that different sets of conditions are required for the establishment of functional GABA and glutamate synapses, the latter necessitating more developed neurons that have apical dendrites that reach the lacunosum moleculare region.

Key words: $C A 1$ pyramidal cells; development; $G A B A_{A}$ receptors; AMPA receptors; NMDA receptors; synaptic transmission

ceptors (NMDARs) (Petralia et al., 1999). The percentage of silent synapses decreases during development with the progressive colocalization of AMPA with NMDA receptors to the synaptic site (Durand et al., 1996; Hsia et al., 1998; Petralia et al., 1999) and could be mediated by neuronal activity (Malenka and Nicoll, 1997).

In spite of the importance of the CA1 hippocampal region in studies on developmental neurobiology and plasticity, the relation between the morphological and physiological properties of pyramidal cells has not been studied. This is important because the suggested sequential maturation of GABA and glutamate synapses is not caused by a sequential arrival of afferent axons. Indeed, both GABAergic (Rozenberg et al., 1989; Dupuy and Houser, 1996) and glutamatergic fibers (Super and Soriano, 1994; Super et al., 1998) are present in the hippocampus before birth. An alternative possibility is that different sets of conditions are required for the establishment of GABA and glutamate synapses and specifically that the degree of maturation of the target cell is an important factor. In keeping with this: (1) the $\gamma 2$ subunit of the $\mathrm{GABA}_{\mathrm{A}}$ receptors that is required for the synaptic targeting of $\mathrm{GABA}_{\mathrm{A}}$ receptors (Essrich et al., 1998) is only expressed when cells have reached a certain degree of maturation (Killisch et al., 1991); (2) glutamate receptors reach the synaptic active zone only when the dendritic spine has been formed (Rao et al., 1998); and (3) dendritic filopodia initiate physical contacts with nearby axons and thus play an important role in synaptogenesis (Ziv and Smith, 1996). Here, we have performed a morphofunctional analysis of CA1 pyramidal cells at birth and demonstrate that the establishment of GABAergic and glutamatergic synapses is sequential and 
A

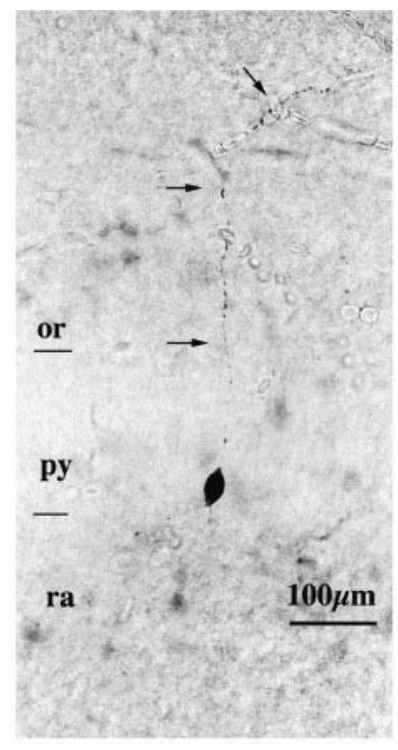

D

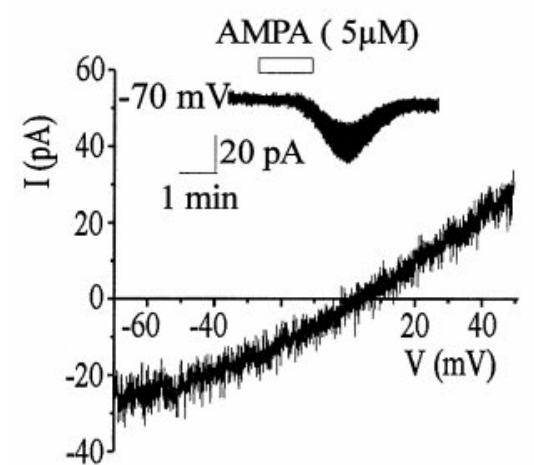

B

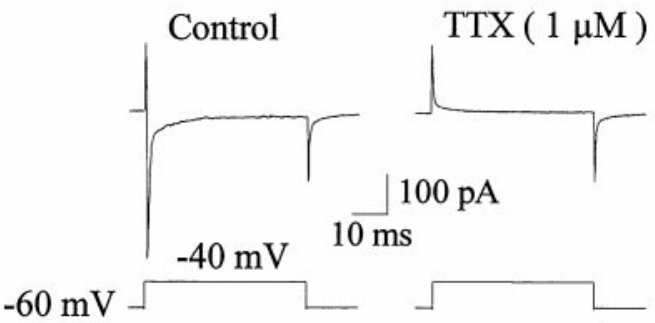

2

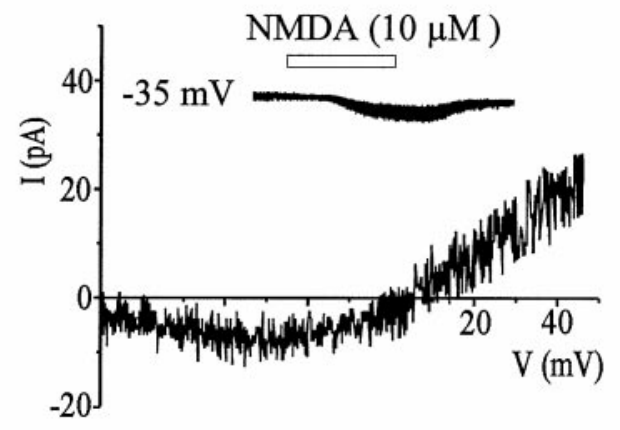

C
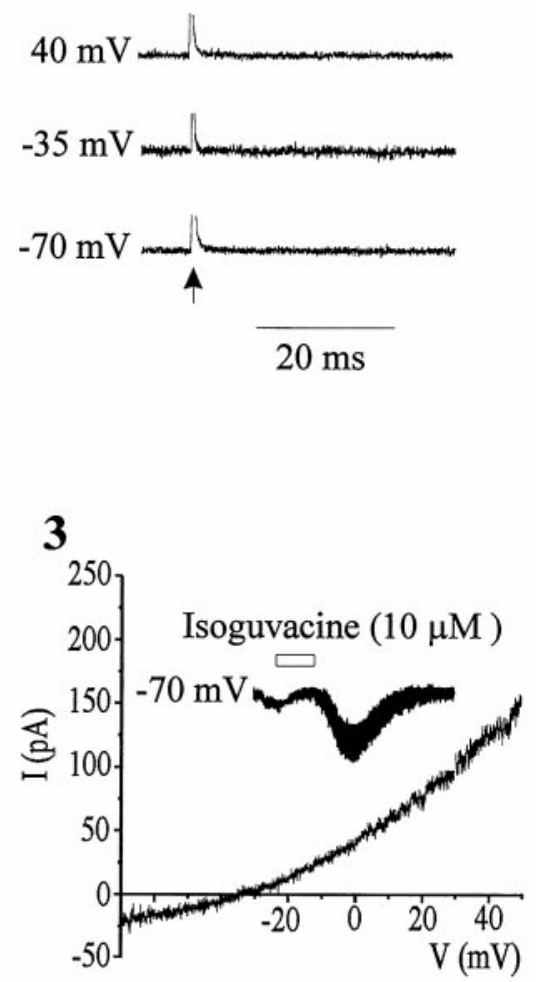

Figure 1. Morphof unctional characteristics of a silent cell. $A$, This representative cell has just an anlage of apical dendrite and no basilar dendrite. In contrast, a long axon is observed in the stratum oriens (arrows). B, A $20 \mathrm{mV}$ depolarizing step for 50 msec evoked a fast inward $\mathrm{Na}^{+}$current that was blocked by bath application of TTX $(1 \mu \mathrm{M})$ (the capacitive current has been truncated). $C$, Electrical stimulations $(50-100 \mathrm{~V}, 30 \mu$ sec duration) of the stratum radiatum did not evoke synaptic currents at these three membrane potentials (mean of 10 traces evoked at $0.05 \mathrm{~Hz}$ ). The truncated stimulation artifact is indicated by an arrow. $D_{1}$, Current-voltage $(I-V)$ relationship of AMPA receptor-mediated response. The insert shows the current generated by bath application of AMPA $(5 \mu \mathrm{M}, 1.5 \mathrm{~min})$ at $-70 \mathrm{mV} . D_{2}, I-V$ relationship of NMDA receptor-mediated response. The insert shows the current generated by bath application of NMDA $(10 \mu \mathrm{M}, 3 \mathrm{~min})$ at $-35 \mathrm{mV} . D_{3}, I-V$ relationship of isoguvacine-mediated response. The current generated by bath application of isoguvacine $(10 \mu \mathrm{M}, 1 \mathrm{~min})$ at $-70 \mathrm{mV}$ is shown in the insert. or, Stratum oriens; $p y$, stratum pyramidale; ra, stratum radiatum.

correlates with the degree of development of the CA1 pyramidal cell apical dendrite.

\section{MATERIALS AND METHODS}

Experiments were performed on CA1 hippocampal slices obtained from male Wistar rats on the day of birth.

Slice preparation. After killing the rat by decapitation, the brain was rapidly removed and placed in oxygenated ice-cooled artificial CSF (ACSF) with the following composition (in $\mathrm{mM}$ ): $126 \mathrm{NaCl}, 3.5 \mathrm{KCl}, 2$ $\mathrm{CaCl}_{2}, 1.3 \mathrm{MgCl}_{2}, 25 \mathrm{NaHCO}_{3} 1.2 \mathrm{NaHPO}_{4}$, and 10 glucose. Hippocampal transverse slices $(350-400 \mu \mathrm{m})$ were cut using Vibratome (VT $1000 \mathrm{E}$; Leica, Nussloch, Germany) and kept in oxygenated $\left(95 \% \mathrm{O}_{2}\right.$ and $\left.5 \% \mathrm{CO}_{2}, \mathrm{pH} 7.3\right)$ ACSF at room temperature at least $1 \mathrm{hr}$ before use. Individual slices were then transferred to the recording chamber where they were fully submerged and superfused with oxygenated ACSF at $30-32^{\circ} \mathrm{C}$ at a rate of $2-3 \mathrm{ml} / \mathrm{min}$.

Electrophysiological recordings. CA1 pyramidal cells were recorded blindly or under visual control (with an axioscope; Zeiss) using patchclamp technique in the whole cell-configuration (Hamill et al., 1981) with an Axopatch 200A (Axon Instruments, Foster City, CA) or EPC9 amplifiers (Heka). Microelectrodes had a resistance of 5-10 M $\Omega$ and filled with a solution of the following composition (in mM): 130 CsGlu, 20 $\mathrm{CsCl}, 0.4 \mathrm{CaCl}_{2}, 1.1$ EGTA, 10 HEPES, $4 \mathrm{Mg}^{2+} \mathrm{ATP}, 0.3 \mathrm{Na}^{+} \mathrm{GTP}$, and biocytin $(0.5-0.8 \%), \mathrm{pH} 7.25,270-280 \mathrm{mOsm}$. Slices were stimulated by a bipolar twisted nichrome electrode placed in the stratum radiatum of CA1 with an intensity that ranges between 10 and $100 \mathrm{~V}$ amplitude, has a $30 \mu \mathrm{sec}$ duration, and a frequency of $0.05-0.033 \mathrm{~Hz}$. In some experiments, trains of electrical stimulation $(100 \mathrm{~Hz}, 1 \mathrm{sec})$ were also applied. In addition, to cover most of the stratum radiatum $(\sim 400-600 \mu \mathrm{m}$ diameter), the two branches of the stimulating electrode $(50 \mu \mathrm{m}$ diameter each) were separated at the tip so that one of the branches was placed in the stratum radiatum at the border of the stratum pyramidale and the other close to the stratum lacunosum moleculare.

Synaptic currents and agonist-evoked responses were acquired on a DAT tape recorder (Biological) and into a personal computer using TL1 DMA Labmaster analog-to-digital converter. Data were then analyzed using Acquis software (Gérard Sadoc, Paris, France). Measurement of the capacitance was performed by applying a $5 \mathrm{mV}$ depolarizing voltage step from $-70 \mathrm{mV}$ and the exponential fit of the capacitive current.

Drugs used were: NMDA, AMPA, isoguvacine, 6-cyano-7nitroquinoxaline-2,3 dione (CNQX), bicuculline, and D-2-amino-5phosphonovalerate (D-APV), all purchased from Tocris Neuramin. Te- 


\begin{tabular}{|c|c|c|c|c|}
\hline & $\begin{array}{l}\text { Silent } \\
(n=18)\end{array}$ & $\begin{array}{l}\text { GABA } \\
(n=13)\end{array}$ & $\begin{array}{l}\text { GABA + NMDA } \\
(n=3)\end{array}$ & $\begin{array}{l}\text { GABA + NMDA + AMPA } \\
(n=9)\end{array}$ \\
\hline Soma size $\left(\mu \mathrm{m}^{2}\right)$ & $143 \pm 11$ & $247 \pm 34^{* *}$ & $224 \pm 31$ & $243 \pm 27^{* *}$ \\
\hline Total dendritic length $(\mu \mathrm{m})$ & $97 \pm 28$ & $307 \pm 79^{*}$ & $880 \pm 198$ & $829 \pm 190 * * *, * * * * *$ \\
\hline Total branching points & $1.2 \pm 0.4$ & $4.6 \pm 1^{*}$ & $12 \pm 4$ & $9 \pm 1 * *, * * * *$ \\
\hline Spines/neuron & 0 & $0.7 \pm 0.3^{*}$ & $2 \pm 2$ & $3.4 \pm 1 * * *, * * * *$ \\
\hline \multicolumn{5}{|l|}{ Apical dendrites } \\
\hline Branching points & $1.1 \pm 1$ & $4.2 \pm 1^{*}$ & $8 \pm 2$ & $6.5 \pm 1 * * *$ \\
\hline Length in radiatum $(\mu \mathrm{m})$ & $29 \pm 11$ & $239 \pm 68^{* *}$ & $438 \pm 135$ & $421 \pm 119^{* * *}$ \\
\hline Length in lacunosum-moleculare $(\mu \mathrm{m})$ & 0 & 0 & $139 \pm 48$ & $177 \pm 53 * * *, * * * * *$ \\
\hline \multicolumn{5}{|l|}{ Basilar dendrites } \\
\hline Branching points & 0 & $0.3 \pm 0.1$ & $4 \pm 2$ & $2.8 \pm 1 * *, * * * *$ \\
\hline Length $(\mu \mathrm{m})$ & 0 & $20 \pm 13^{*}$ & $181 \pm 96$ & $167 \pm 54 * * *, * * * * *$ \\
\hline
\end{tabular}

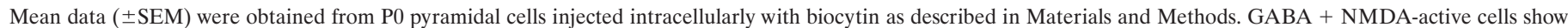
similar values than GABA + NMDA + AMPA-active cells, but statistical analysis was not realized because of the limited number of this type of cells. ${ }^{*} p<0.005 ; * * p<0.001 ; * * p<0.001$ when compared with silent cells.

$* * * p<0.05 ; * * * * * p<0.0001$ when compared with GABA-active cells.

A $\quad$ B

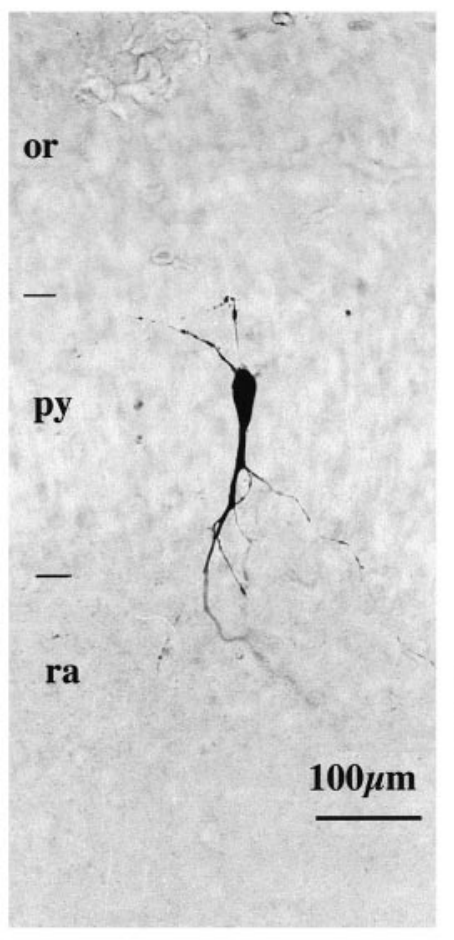

C

\section{Control}

Bicuculline $(10 \mu \mathrm{M})$
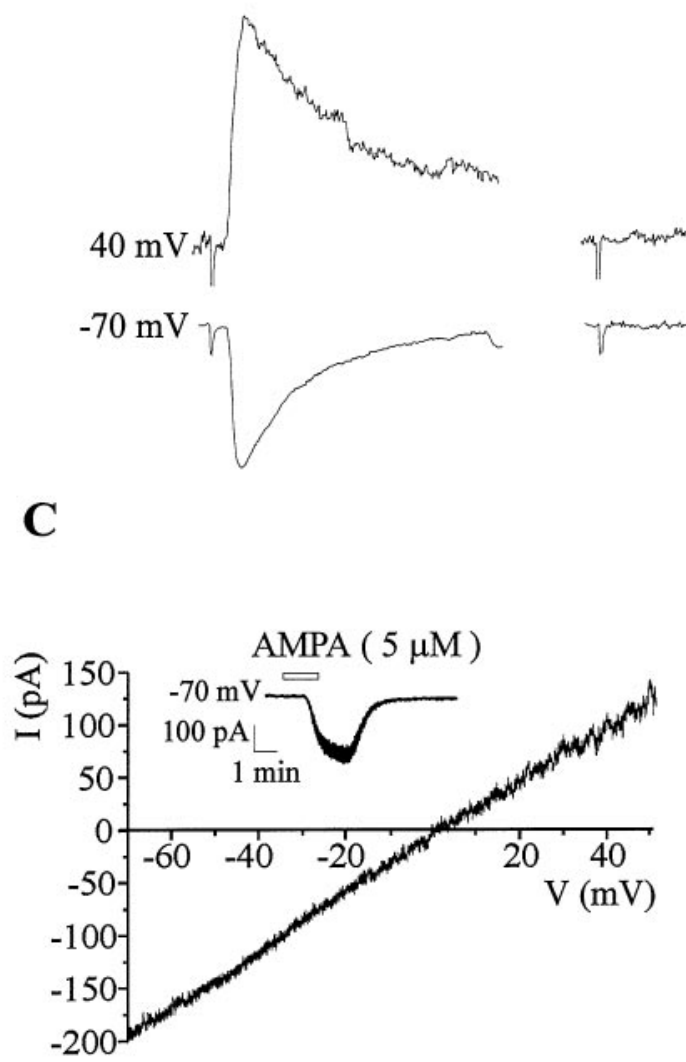

Wash
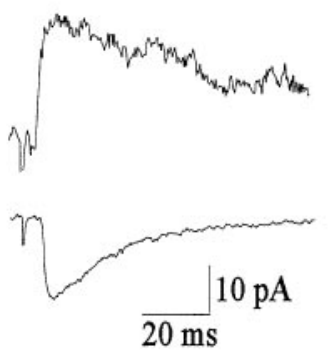

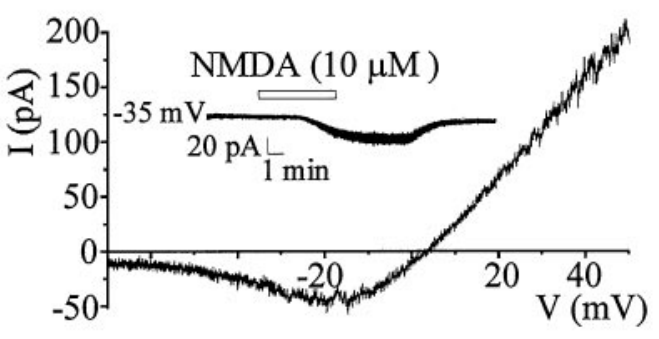

Figure 2. Morphofunctional properties of a neuron with $\mathrm{GABA}_{\mathrm{A}}$ receptor-mediated PSCs. $A$, The soma is bigger than that of silent neurons, and the apical dendrite arborizes in the stratum radiatum. $B$, Electrical stimulation of the stratum radiatum (37 V, $30 \mu$ sec duration) evoked in control a synaptic response that was inward at $-70 \mathrm{mV}$ and outward at $40 \mathrm{mV}$ (each depicted synaptic response is the mean of five traces evoked at $0.05 \mathrm{~Hz}$ ). Bicuculline $(10 \mu \mathrm{M})$ abolished reversibly the synaptic current at both membrane potentials, even when the stimulus intensity was increased (traces in bicuculline represent PSCs evoked at $100 \mathrm{~V}$, whereas the PSC shown after the washout of the antagonist is evoked as in control at $37 \mathrm{~V}$ ). $C, I-V$ relationship of AMPA (left graph) and NMDA (right graph) receptor-mediated currents (inserts depict the AMPA and NMDA currents at -70 and - 35 mV, respectively). 
A

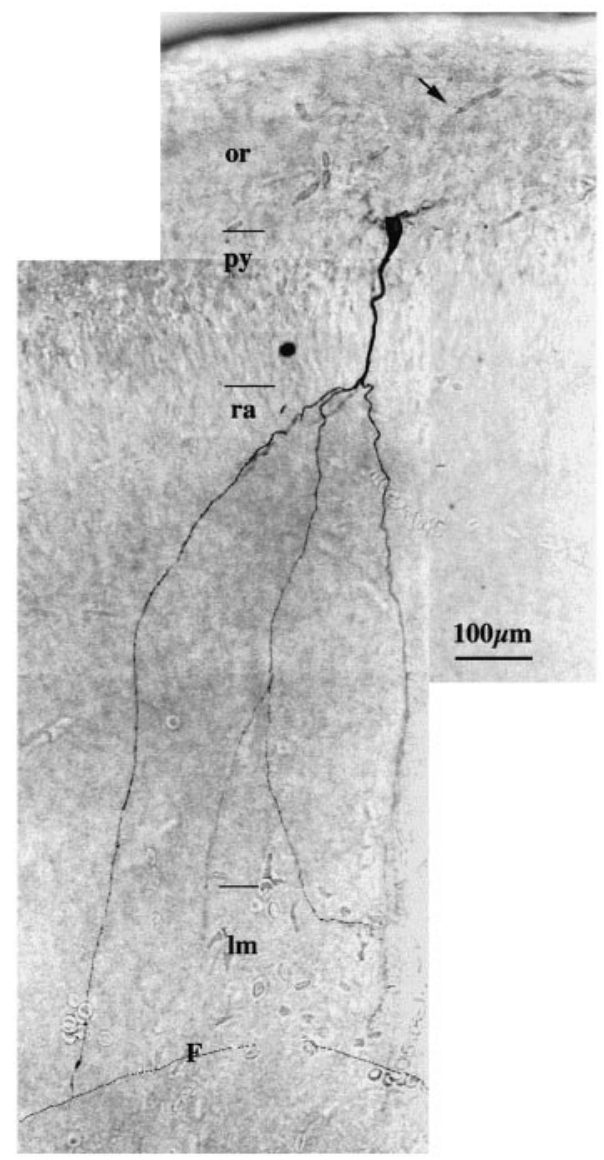

B

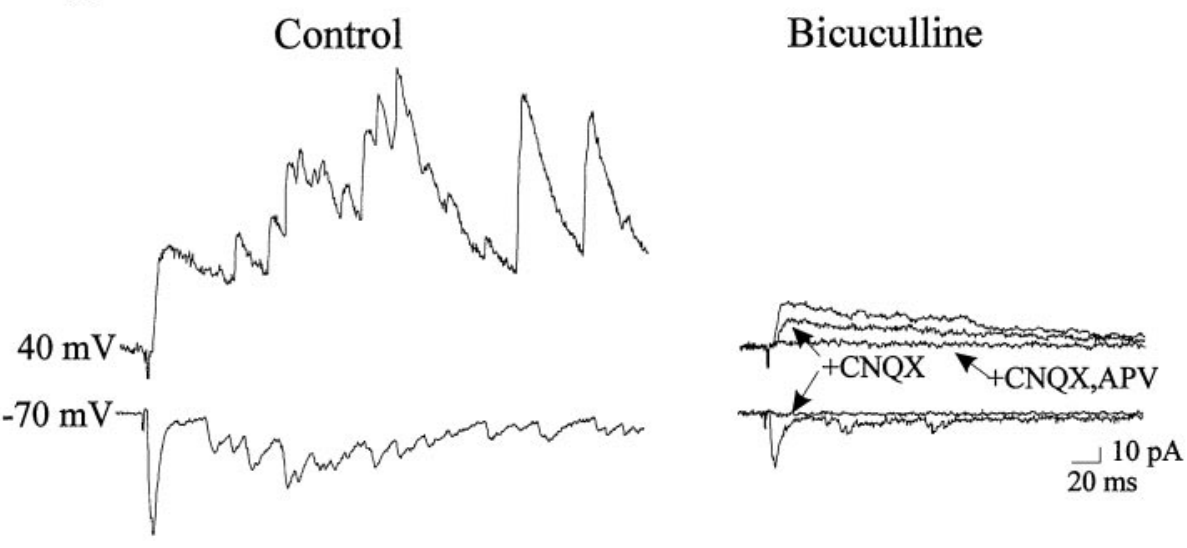

C

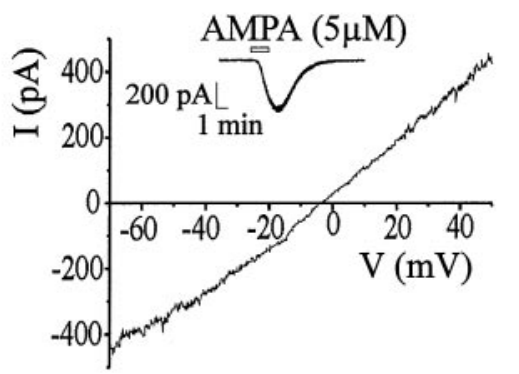

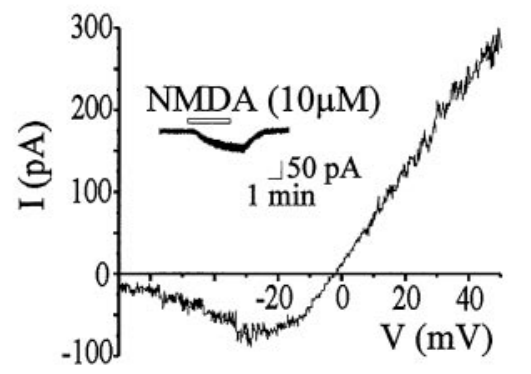

Figure 3. Morphofunctional properties of a neuron with GABA plus AMPA plus NMDA receptor-mediated PSCs. $A$, The apical dendrite reaches the stratum lacunosum moleculare $(\operatorname{lm})$ and crosses the hippocampal fissure (represented by a line, $F$ ). $B$, The neuron has a synaptic response mediated by $\mathrm{GABA}_{\mathrm{A}}, \mathrm{AMPA}$, and NMDA receptors. The stimulation of the stratum radiatum $(60 \mathrm{~V}, 30 \mu \mathrm{sec}$ duration) evoked both at -70 and $40 \mathrm{mV}$ a synaptic response composed of a monosynaptic component and a polysynaptic GDP. Bicuculline $(10 \mu \mathrm{M})$ decreased the monosynaptic component and eliminated the GDP. The remaining response is completely blocked by CNQX $(10 \mu \mathrm{M})$ at $-70 \mathrm{mV}$ and by CNQX and APV (50 $\mu \mathrm{M})$ at $40 \mathrm{mV}$. $C, I-V$ relationship of AMPA receptor-mediated response (left curve) and NMDA receptor-mediated response (right curve). Inserts depict the AMPA and NMDA currents at -70 and $-35 \mathrm{mV}$, respectively.

trodotoxin (TTX), biocytin, and picrotoxin were purchased from Sigma (St. Louis, MO). All these drugs have been dissolved in ACSF and applied to the bath.

Histological processing. To reveal biocytin-injected cells, slices were immerged in a fixative solution of paraformaldehyde (4\%) and glutaraldehyde $(0.2 \%)$ overnight at $4^{\circ} \mathrm{C}$ after electrophysiological recording. To increase penetration of the reagents used for biocytin detection, slices were quickly frozen on dry ice and thawed in phosphate buffer. Slices were then rinsed in $0.05 \mathrm{M}$ Tris-buffered saline (TBS), $\mathrm{pH} 7.4$, containing $0.3 \%$ Triton $\mathrm{X}-100$ for $30 \mathrm{~min}$ and incubated overnight at $4^{\circ} \mathrm{C}$ in an avidin-biotin-peroxidase solution prepared in TBS according to the manufacturers recommendation (Vectastain Elite ABC; Vector Laboratories, Burlingame, CA). After a $30 \mathrm{~min}$ wash in TBS and a $10 \mathrm{~min}$ rinse in Tris buffer (TB), $\mathrm{pH} 7.6$, slices were processed for $15 \mathrm{~min}$ in $0.06 \%$ 3-3-diaminobenzidine tetrahydrochloride and $0.01 \%$ hydrogen peroxide diluted in TB. The slices were then rinsed in TB for 30 min, mounted on gelatin-coated slides, dehydrated, and coverslipped with permount. Stained cells were reconstructed using a camera lucida. Size and branching pattern were analyzed using the Samba/2005, TITN software (Alcatel, France).

The distribution of synaptic proteins was analyzed using mouse antisynaptophysin (1: 500) and rabbit anti-synapsin-1 (1: 1000) (both are from Chemicon, Temecula, CA). This was performed on slices used for electrophysiology (see above) or from rats anesthetized with pentobarbital and transcardially perfused with $4 \%$ paraformaldehyde and $0.5 \%$ glutaraldehyde, because the number of synapses could differ in both materials (Kirov and Harris, 1999). Coronal or sagittal 40- $\mu$ m-thick sections were incubated overnight with primary antibodies and, after washing, immunoreactivity was revealed using anti-mouse or anti-rabbit biotin-conjugated antibodies and the avidin-biotin system.

Statistical analysis. Data are expressed as mean \pm SEM. Statistical significance of difference between means was assessed with ANOVA and $t$ test, and the level of significance was set at $p<0.05$.

\section{RESULTS}

\section{Three stages of CA1 pyramidal cell maturation in newborn rats}

In a first group of experiments, 60 CA1 neurons were blindly recorded (in the medial part of CA1) from the pyramidal cell layer in the whole-cell configuration (Hamill et al., 1981) and often injected with biocytin and reconstructed post hoc. These cells were identified as neurons (vs glia) because depolarizing steps $(20 \mathrm{mV}$, from $-60 \mathrm{mV})$ evoked a fast TTX-sensitive inward sodium current (Fig. 1B). They were identified as pyramidal neurons on the basis of the morphological reconstruction (see Fig. 6 ); by its location within the pyramidal cell layer, the presence of an axon originated from the basilar part of the cell body and reached the alveus and the formation of a single apical dendrite 
A

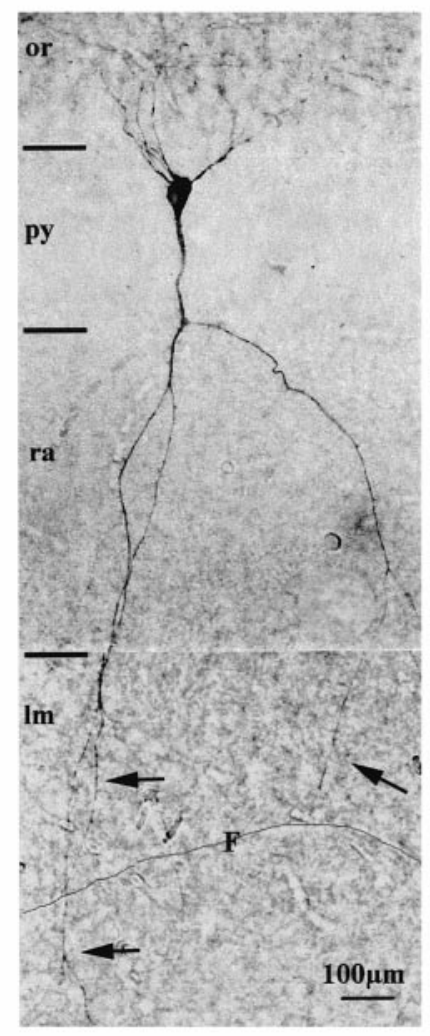

B

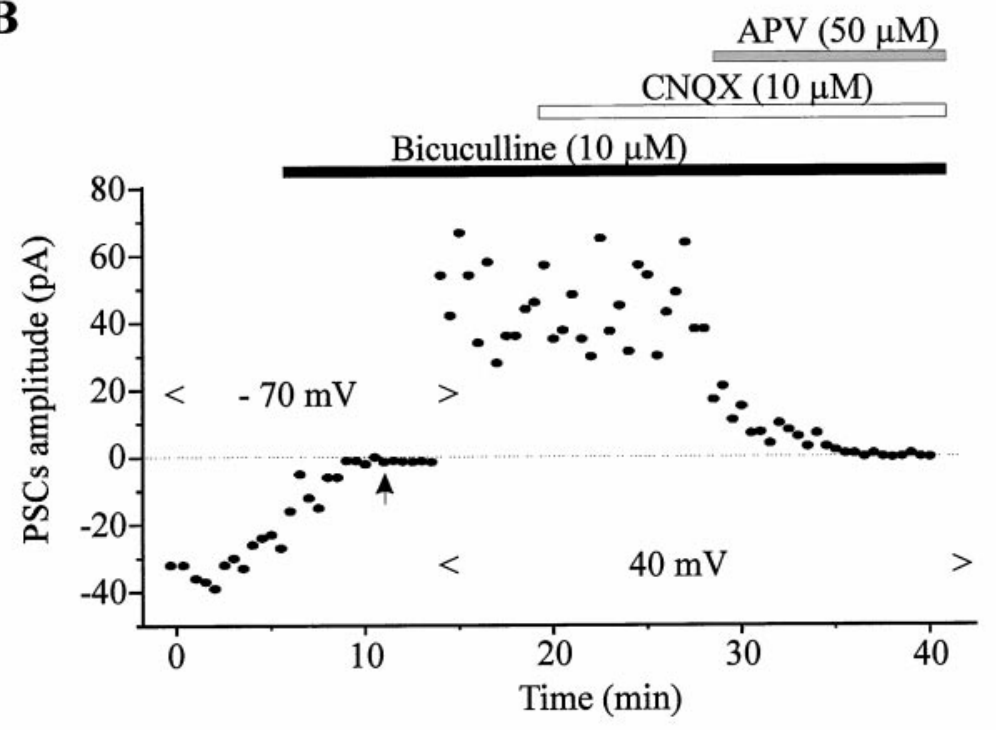

C

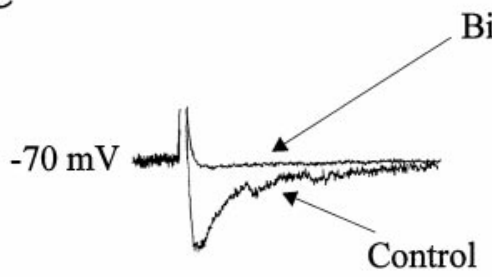

Bic.

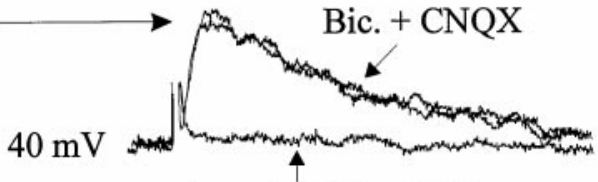

Bic. $+\mathrm{CNQX}+\mathrm{APV}$

Figure 4. Morphof unctional characteristic of a neuron with GABA plus NMDA receptor-mediated PSCs. $A$, Note that this cell has a similar shape to the one shown in Figure $3 A$. B , Plot of the amplitude of the PSCs versus time. In control, the stimulation intensity was $50 \mathrm{~V}$. Application of bicuculline $(10 \mu \mathrm{M})$ completely blocked the synaptic response evoked at $-70 \mathrm{mV}$. Increasing the stimulus intensity to $100 \mathrm{~V}$ (indicated by the arrow) failed to restore any synaptic response. After holding the membrane potential at $40 \mathrm{mV}$, the same stimulus intensity evoked an outward synaptic response that is insensitive to CNQX but completely blocked by further application of APV (50 $\mu \mathrm{M})$. $C$, PSCs corresponding to the graph depicted in $B$. Each trace is the average of five consecutive PSCs. The control PSC at $-70 \mathrm{mV}$ is evoked at $50 \mathrm{~V}$, whereas others are evoked at $100 \mathrm{~V}$.

perpendicularly oriented to the hippocampal fissure. Although not analyzed in detail, bicuculline-sensitive network-driven spontaneous giant depolarizing potentials (GDPs) were sometimes recorded (data not shown) in keeping with earlier observations (Ben-Ari et al., 1989; Khazipov et al., 1997). Based on their synaptic spontaneous and evoked activities and their morphological features, these neurons could be classified into three groups: (1) neurons with no spontaneous or evoked postsynaptic currents (PSCs) (silent neurons); (2) neurons with $\mathrm{GABA}_{\mathrm{A}}$ but not glutamate PSCs (GABA-only neurons); and (3) neurons with $\mathrm{GABA}_{\mathrm{A}}$ and glutamate (NMDA-only or NMDA plus AMPA) PSCs.

\section{Silent neurons}

In 46 neurons, there was no spontaneous activity, even in conditions that favor transmitter release, such as elevating $\left[\mathrm{K}^{+}\right]_{\mathrm{o}}$ concentration (to $10 \mathrm{~mm}$ ) to increase cell excitability or increasing osmolarity by the addition of sucrose $(50 \mathrm{~mm})$ to the bath (see Fig. $5 A_{2}$ ). Electrical stimulation (at least for $10 \mathrm{~min}$ ) of the strata lacunosum moleculare, radiatum, pyramidale, and oriens did not evoke a synaptic response at a wide range of stimulus intensities and membrane potentials (Fig. $1 C$; see Fig. $5 A_{2}$ ). Furthermore, tetanic stimulation of the stratum radiatum $(100 \mathrm{~Hz}, 1 \mathrm{sec})$ failed to generate PSCs (data not shown). These neurons express, however, ionotropic glutamate and $\mathrm{GABA}_{\mathrm{A}}$ receptors because, in the presence of TTX (1 $\mu \mathrm{M})$, bath application of: (1) AMPA (5 $\mu \mathrm{M}, 1.5 \mathrm{~min})$ generated, at $-70 \mathrm{mV}$, an inward current of $22.4 \pm$ $2.8 \mathrm{pA}(n=29)$ that reversed polarity at $4.1 \pm 2.8 \mathrm{mV}(n=7)$, with a slope conductance of $0.26 \pm 0.07 \mathrm{nS}$ (Fig. $\left.1 D_{1}\right)$. (2) NMDA (10 $\mu \mathrm{M}, 3 \mathrm{~min})$ generated a small inward current at $-35 \mathrm{mV}$ of $4 \pm 1.1 \mathrm{pA}(n=16)$ that reversed polarity at $0.6 \pm 5.2 \mathrm{mV}(n=$ $3)$. The current-voltage $(I-V)$ relationship showed a region of negative slope conductance with a peak inward current in the -20 to $-35 \mathrm{mV}$ range and mean slope conductance in the linear part of the curve of $0.49 \pm 0.09 \mathrm{nS}$ (Fig. 1 $D_{2}$ ). (3) The GABA receptor agonist isoguvacine $(10 \mu \mathrm{M}, 1 \mathrm{~min})$, generated, at -70 $\mathrm{mV}$, an inward current of $18.6 \pm 2.1 \mathrm{pA}(n=26)$ that reversed polarity at $-32 \pm 3.8 \mathrm{mV}(n=3)$. The $I-V$ relationship of $\mathrm{GABA}_{\mathrm{A}}$ currents was not totally linear and showed an outward rectification for values more positive than the reversal potential (Fig. 1D $D_{3}$ (Blanton and Kriegstein, 1992; Serafini et al., 1998). Therefore, glutamate and $\mathrm{GABA}_{\mathrm{A}}$ receptors are expressed before the presence of spontaneous or evoked synaptic currents as in other structures (Blanton and Kriegstein, 1992; Walton et al., 1993; Chen et al., 1995; LoT urco et al., 1995; Serafini et al., 1998).

Silent neurons have a low capacitance $18.1 \pm 0.7 \mathrm{pF}(n=46)$, and their morphological reconstruction $(n=18$; Fig. $1 A$; see Figs. $6,8 A$ ) revealed a small round-shaped soma $\left(143 \pm 11 \mu \mathrm{m}^{2}\right)$ and an anlage of apical dendrite that was either entirely restricted to 


\section{$\mathbf{A}_{1}$}

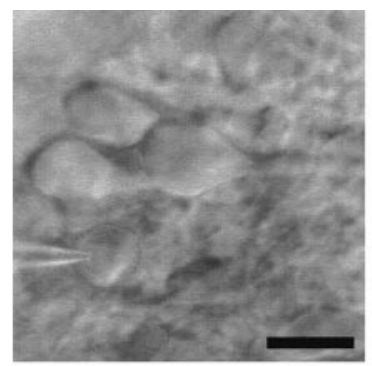

$\mathbf{B}_{\mathbf{1}}$

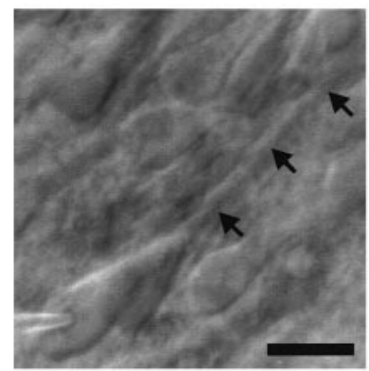

$\mathbf{C}_{1}$

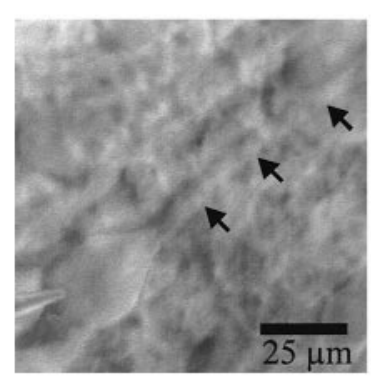

2

Control
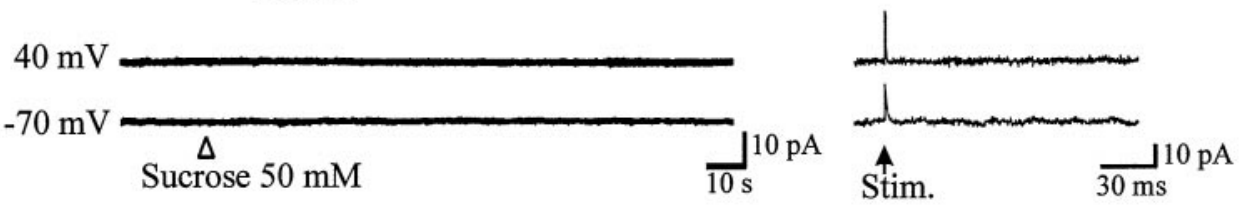

\section{2}

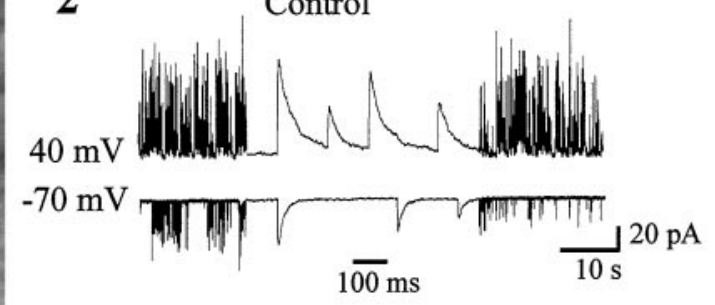

Control

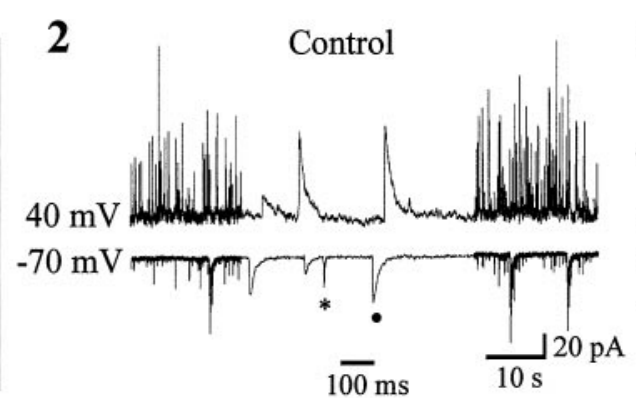

Bicuculline

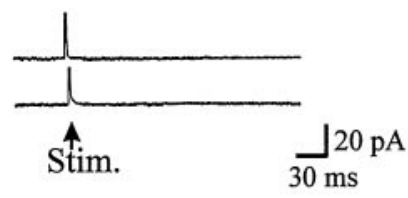

Figure 5. Visual identification of silent and active neurons. $A_{1}$, Silent cell $\left(\mathrm{C}_{\mathrm{m}}, 10 \mathrm{pF}\right)$ with round shape soma and no apical dendrite. $A_{2}$, Bath application of sucrose $(50 \mathrm{~mm})$ or stimulation of the stratum radiatum $(100 \mathrm{~V}, 30 \mu \mathrm{sec}$ duration) failed to evoke any synaptic response both at -70 and $40 \mathrm{mV} . \mathrm{B}_{1}$, GABA-active neuron $\left(\mathrm{C}_{\mathrm{m}}, 27 \mathrm{pF}\right)$ from the same slice has a bigger soma and an apical dendrite (arrows). $B_{2}$, The spontaneous activity is completely blocked by bicuculline $(10 \mu \mathrm{M})$. In the presence of the antagonist, stimulation of the stratum radiatum (100 V, $30 \mu$ sec duration) failed to evoke a PSC at -70 and $40 \mathrm{mV}$ (mean of 10 traces evoked at $0.05 \mathrm{~Hz}$ ). $\mathrm{C}_{1}$, GABA plus Glu-active cell from another slice $\left(\mathrm{C}_{\mathrm{m}}, 40 \mathrm{pF}\right) . C_{2}, \mathrm{Note}$ that AMPA receptor-mediated PSCs (asterisk) can easily be distinguished from GABA PSCs ( filled circle) at $-70 \mathrm{mV}$ by the different decay time constant $(\tau=1.33 \mathrm{msec}, \tau=19.76 \mathrm{msec}$, respectively).

the stratum pyramidale (15 of 18$)$ or distributed exclusively within the inner $50 \mu \mathrm{m}$ part of the stratum radiatum $(n=3$ of 18). The apical dendrite was poorly arborized with few branching points $(1.1 \pm 1)$ and no spines and, with one exception, no basilar dendrites (Table 1). In contrast, axons were relatively well developed, walked throughout the stratum oriens, and reached the alveus. Therefore, the majority of blindly recorded CA1 pyramidal neurons had no synaptic activity, no dendritic arborization, and a small capacitance. As depicted in Figure 6, silent cells did not show a preferential location in the stratum pyramidale and were observed either close to the stratum radiatum or close to the stratum oriens.

\section{Neurons that have GABA PSCs only}

In eight neurons, both spontaneous and evoked PSCs by the stimulation of the stratum radiatum were recorded that were mediated only by $\mathrm{GABA}_{\mathrm{A}}$ receptors because they were blocked by bicuculline $(10 \mu \mathrm{M})$ or picrotoxin $(100 \mu \mathrm{M})$ (Fig. $2 B$; see Fig. $5 B_{2}$ ) and reversed polarity at a value close to the reversal potential of the current generated by isoguvacine (data not shown). This population of neurons was more mature than the previous group with: (1) a significantly higher capacitance $25.2 \pm 3 \mathrm{pF}(n=$ $8 ; p=0.01) ;(2)$ a significantly larger somatic size $(221.7 \pm 37.2$ $\mu \mathrm{m}^{2} ; p=0.017 ; n=4$ cells); (3) a more developed apical dendrite that arborized within the stratum radiatum and the presence of basilar dendrite or dendrites (Fig. $2 A$; see Figs. 6, $8 A$ ); and (4) significantly larger currents generated by bath applications of glutamate agonists. Thus, in the presence of bicuculline $(10 \mu \mathrm{M})$ and TTX $(1 \mu \mathrm{M})$, bath application of AMPA $(5 \mu \mathrm{M}, 1.5 \mathrm{~min})$ at $-70 \mathrm{mV}$ generated an inward current of $164 \pm 22 \mathrm{pA}(n=6 ; p=$ $10^{-10}$ when compared with silent cells) with a mean slope conductance of $1.9 \pm 0.4 \mathrm{nS}(p=0.002$; Fig. $2 C)$. Similarly, bath application of NMDA $(10 \mu \mathrm{M}, 3 \mathrm{~min})$ generated, at $-35 \mathrm{mV}$, inward currents of $16 \pm 4 \mathrm{pA}$ with a mean slope conductance measured in the linear part of the curve of $1.1 \pm 0.2 \mathrm{nS}(n=4$; $p=0.04)$. Therefore, CA1 pyramidal neurons that have functional $\mathrm{GABA}_{\mathrm{A}}$, but not glutamate, PSCs are more mature than silent cells.

\section{Neurons with GABA and glutamate PSCs}

In five recorded neurons, both spontaneous and evoked PSCs mediated by $\mathrm{GABA}_{\mathrm{A}}$ and glutamate receptors were recorded (Fig. $3 B$; see Fig. $5 C_{2}$ ). Electrical stimulation of the stratum radiatum evoked a synaptic response that, at $-70 \mathrm{mV}$, was partially reduced by bicuculline $(10 \mu \mathrm{M})$ and completely eliminated by a subsequent application of CNQX $(10 \mu \mathrm{M})$. Holding the 


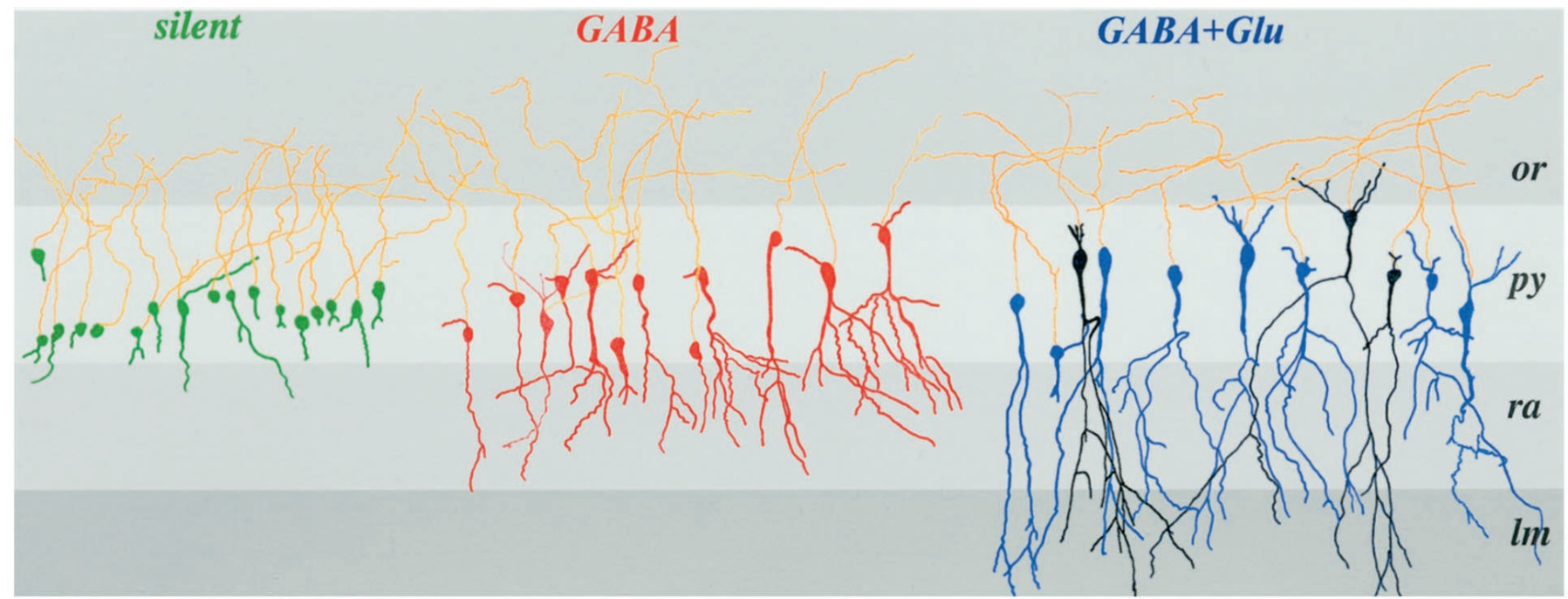

Figure 6. Camera lucida reconstruction of injected P0 pyramidal cells grouped accordingly to their synaptic properties. The neurons not represented here are shown in Figure 8A. Silent cells are shown in green, GABA-only in red, and neurons with GABA and NMDA or GABA plus NMDA plus AMPA receptor-mediated PSCs are in black and blue, respectively. Note that each group of cells has a relative homogenous degree of maturation. GABA-active and GABA plus glutamate-active neurons differ essentially by the presence of an apical dendrite in the stratum lacunosum moleculare. Note also that there are no morphological differences between GABA plus NMDA and GABA plus NMDA plus AMPA-active cells.

Table 2. Mean capacitance and statistical values of cells

\begin{tabular}{lll} 
Type & Reconstructed & Not Reconstructed \\
\hline Silent & A, $18.9 \pm 1.2(n=18)$ & B, $16.9 \pm 0.8(n=37)$ \\
GABA & C, $31.8 \pm 2.6(n=13)$ & D, 28.1 $\pm 1.3(n=18)$ \\
GABA + NMDA & E, $46.5 \pm 5.7(n=3)$ & \\
$\begin{array}{l}\text { GABA + NMDA + } \\
\text { AMPA }\end{array}$ & F, $45 \pm 5.1(n=9)$ & G, $44.9 \pm 2.1(n=21)$ \\
\hline
\end{tabular}

\begin{tabular}{|c|c|c|c|c|c|}
\hline A & B & $\mathrm{C}$ & $\mathrm{D}$ & E & $\mathrm{F}$ \\
\hline $\begin{array}{l}\text { B } \quad p=0.2 \\
\text { C * } p=10^{-5}\end{array}$ & & ${ }^{*} p=10^{-10}$ & & ${ }^{*} p=210^{-10}$ & ${ }^{*} p=10^{-11}$ \\
\hline $\mathrm{D} * p=210^{-5}$ & ${ }^{*} p=10^{-8}$ & $p=0.2$ & & ${ }^{*} p=210^{-4}$ & ${ }^{*} p=0.001$ \\
\hline $\mathrm{E}^{*} p=10^{-6}$ & & ${ }^{*} p=0.04$ & & & \\
\hline $\mathrm{F} * p=10^{-6}$ & & ${ }^{*} p=0.028$ & & $p=0.93$ & \\
\hline $\mathrm{G}^{*} p=10^{-12}$ & ${ }^{*} p=10^{-11}$ & ${ }^{*} p=710^{-4}$ & ${ }^{*} p=210^{-6}$ & $p=0.73$ & $p=0.98$ \\
\hline
\end{tabular}

Mean capacitance of each group of cells reconstructed and not reconstructed classified according to their synaptic properties (top table). The bottom table represents the statistical values when one group of cells was compared to another group.

Asterisks indicate that the difference is significantly different $(p<0.05$; ANOVA test).

membrane potential at $40 \mathrm{mV}$ revealed an outward synaptic current that was reduced by bicuculline and CNQX and completely blocked by further application of APV $(50 \mu \mathrm{M})$, reflecting the participation of NMDA receptors in the synaptic response. In one neuron, glutamatergic activity was mediated by NMDA but not by AMPA receptors, i.e., the synaptic response at $-70 \mathrm{mV}$ was eliminated by bicuculline, whereas at $40 \mathrm{mV}$ a CNQXinsensitive synaptic response was observed that was fully blocked by APV $(50 \mu \mathrm{M})$ (Fig. $4 B, C)$. The converse, AMPA but not NMDA receptor-mediated PSCs, was not observed.

Neurons with GABA and glutamate PSCs had a significantly higher capacitance than the GABA-active cells $(46.2 \pm 4.5 \mathrm{pF}$; $p=0.006)$. They also had significantly larger currents generated by AMPA and NMDA because in the presence of bicuculline and TTX, bath application of: (1) AMPA (5 $\mu \mathrm{M}, 1.5 \mathrm{~min})$ generated, at $-70 \mathrm{mV}$, a mean inward current of $309 \pm 48 \mathrm{pA}(n=5 ; p=$ $0.005)$ with a mean slope conductance of $4.3 \pm 0.6 \mathrm{nS}(p=0.004)$ (Fig. $3 C$ ); (2) NMDA (10 $\mu \mathrm{M}, 3 \mathrm{~min})$ generated a mean inward current at $-35 \mathrm{mV}$ of $38 \pm 6.3 \mathrm{pA}(n=5 ; p=0.009)$ and with a mean slope conductance measured in the linear part of the curve of $3.3 \pm 0.4 \mathrm{nS}(p=0.004)$ (Fig. $3 C)$. These cells have a higher level of morphological maturation than GABA-active cells because their apical dendrite reached the stratum lacunosum moleculare (Figs. 3A, 4A; see Figs. 6, $8 A$ ), and they have also basilar dendrites.

However, the quantitative comparison of the morphological differences between this group and the neurons with GABA PSCs only is precluded by the limited number of neurons. We therefore used patch recordings under visual control to increase the number of neurons with synaptic currents.

\section{Visual patch recordings confirm the differences between the two populations of active neurons}

Because blind patch studies suggest that active neurons have larger soma and a more extended apical dendrite, we recorded under visual control pyramidal neurons with these features. All 51 neurons recorded had PSCs, 24 had only GABA, and 27 had GABA and glutamate PSCs, including two neurons in which the synaptic activity was mediated by GABA and NMDA but not AMPA receptors. The nine additional neurons that were recorded under visual control with small soma and no apparent dendrite were, as expected, not active (Figs. 5, 6). Pooling the data from blind and visual patch recordings suggests that neurons with GABA and glutamate PSCs are more mature than neurons with GABA PSCs only (Table 1). This conclusion is supported by the following observations: (1) the apical dendrite of the neurons with GABA and glutamate PSCs reached the stratum lacunosum moleculare and arborized within this layer; in contrast the apical dendrite of neurons with GABA PSCs only were exclusively restricted to the stratum radiatum. (2) The basilar dendrite of neurons with GABA and glutamate PSCs are more developed (length, number of branching points) than neurons with GABA PSCs only, although the number of cells in which these dendrites 
A

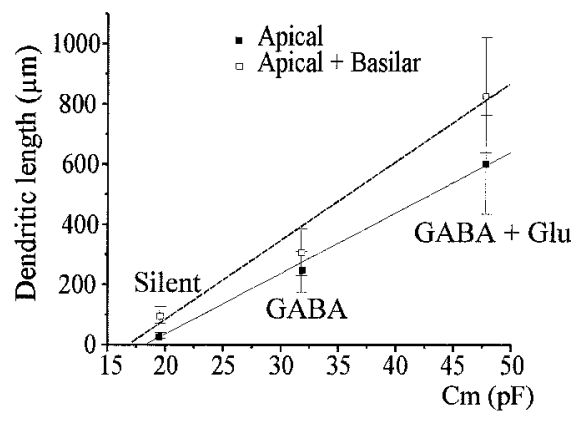

B

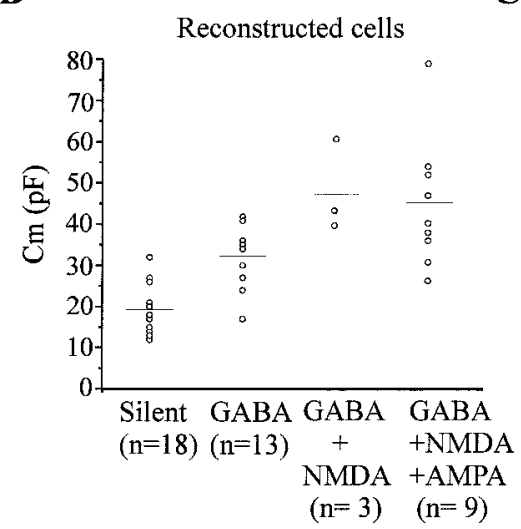

C

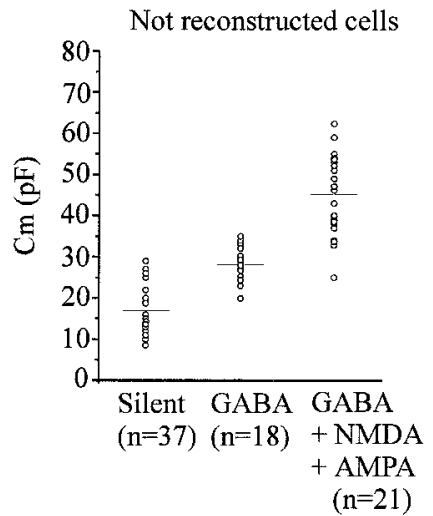

Figure 7. The three different types of cells can be differentiated by their dendritic length and their capacitance. $A$, The apical or total (apical plus basilar) dendritic length of silent, GABA, and GABA plus Glu (NMDA-only and NMDA plus AMPA)-active cells are plotted according to their mean capacitance. $B$, The capacitance of all reconstructed cells is plotted according to their synaptic properties. The mean capacitance (indicated by a horizontal bar) of each cell type is significantly different from the other types (mean values and statistics are depicted in Table 2). $C$, The capacitance of all nonreconstructed cells are plotted according to their synaptic properties. As in $B$ there is some overlap between the values, but here again the mean capacitance of each group is significantly different from the other populations.

are observed was similar ( $n=9$ of 12 and 8 of 13 , respectively). With one exception, the basilar dendrite did not reach the stratum oriens. (3) Although the number of spines at this stage was small in the neurons with GABA PSCs only and GABA plus glutamate PSCs (one to three and one to nine spines, respectively), they were more frequently observed in the latter ( 7 of 12 cells) than in the former group (4 of 13 cells).

This comparison is based on the entire population of neurons with glutamate PSCs (i.e., NMDA-only and NMDA plus AMPA) because there were no morphological difference between glutamate-silent and glutamate-active neurons. As shown in Tables 1 and 2, these were similar in terms of capacitance, size of the soma, total dendritic length, number of branching points, number of dendritic spines, and presence of basal dendrites.

Neuronal capacitance is a good predictor of the degree of maturation of the neurons. The capacitance of the three populations of neurons were significantly different (Table 2) with a strong correlation between the mean capacitance and the mean dendritic length (basilar plus apical or apical only) $\left(r^{2}=0.99\right)$ (Fig. 7A). These observations suggest that the neuronal capacitance enables one to predict the morphological properties of the cells. Because these analyses relied only on successfully reconstructed neurons, we also compared the capacitance of the three groups of cells that have not been reconstructed with those for which the morphology was available. As shown in Table 2 and Figure $7, B$ and $C$, there was no statistical difference between reconstructed and nonreconstructed neurons, suggesting that they have similar developmental profiles.

\section{Synaptic markers are not detected in the stratum pyramidale}

Our data suggests that the first synapses established on pyramidal neurons are localized in the stratum radiatum. We have tested this hypothesis by analyzing the distribution of synaptophysin and synapsin-1, 2 synaptic markers on slices made from the brain of perfused rats. Immunoreactive boutons were present in the stratum radiatum (Fig. $8 B, C$ ) and also in the stratum oriens and lacunosum moleculare (data not shown) but not in the stratum pyramidale ( $n=5$ of 5 ). Because slices made from the brains of nonperfused animals differ in the number of synapses from those of perfused rats (Kirov and Harris, 1999), we also performed immunohistochemical staining on slices used for electrophysiology. We found in this material the same distribution of synaptophysin and synapsin- 1 as in slices from perfused rats $(n=4$ of 4 ; data not shown) (we have however not quantified the number of synaptic boutons in both materials). Therefore, neurons with an anlage of apical dendrite are silent because they have no synapses and peridendritic GABAergic synapses are established before perisomatic ones, in keeping with immunocytochemical observations (Rozenberg et al., 1989; Dupuy and Houser, 1996).

\section{DISCUSSION}

The present data show that at birth most CA1 pyramidal neurons are silent, with no synaptic currents, and provide direct evidence for a sequential participation of GABAergic and glutamatergic receptors in synaptic transmission. Our study provides to the best of our knowledge the first evidence that this sequence is correlated with morphological changes: increase in length of dendrite, increase of somatic size, and whole-cell capacitance. It is in fact possible to predict on the basis of these measurements whether the neuron is silent, has GABAergic-only, or GABAergic and glutamatergic functional synapses. The presence of a small apical dendrite in the stratum radiatum is a necessary and sufficient morphological requirement for the formation of functional GABA synapses, whereas glutamate synapses require a more developed dendrite that reaches the stratum lacunosum moleculare (Fig. 9a). Therefore, dendritic growth may be modulated in a first stage (when the apical dendrite of the pyramidal neuron is restricted to the stratum radiatum) by GABAergic synaptic activity, whereas at a subsequent stage (once it has penetrated in the lacunosum moleculare), glutamate receptor activity takes over the control of dendritic dynamics. A small percentage of neurons have glutamate silent synapses (PSCs mediated by NMDARs only). These neurons have a similar degree of development as neurons with glutamate "active" synapses [PSCs mediated by NMDA and AMPA receptors (AMPARs)], suggesting that in the hippocampus the activity-dependent acquisition of synaptic AMPARs (Malenka and Nicoll, 1997) is a rapid process that does 

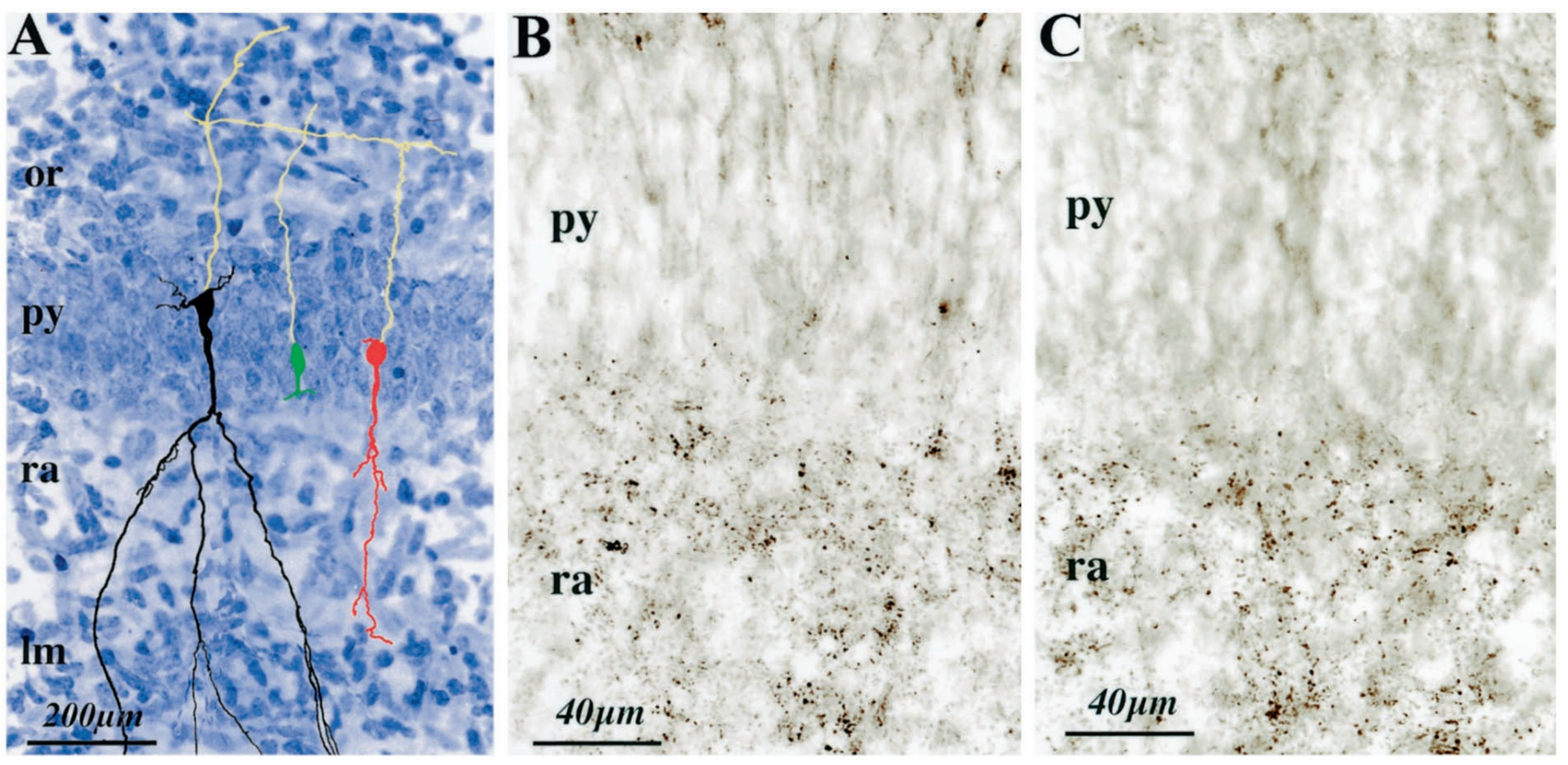

Figure 8. Synaptic boutons are present in the stratum radiatum but not in the stratum pyramidale. $A$, CA1 hippocampal section stained with cresyl violet. Three pyramidal cells not shown in Figure 6, the silent (green), GABA-only (red), and GABA plus NMDA plus AMPA-active neurons (black) are represented (camera lucida reconstruction) to show the distribution of the dendrites within all the layers. $B, C$, Other sections from the same hippocampus depict immunolabeling with synaptophysin $(B)$ and Synapsin-1 $(C)$ in the stratum radiatum but not in the stratum pyramidale.

not require further maturation of the neurons (but see Wu et al., 1996; Rajan and Cline, 1998).

\section{Heterogeneity of CA1 pyramidal cells at birth}

Our morphofunctional data suggest that: (1) pyramidal neurons are heterogeneous at birth probably because of the duration of their neurogenesis from embryonic day 16 (E16) to E20 (Bayer, 1980). The large majority of silent cells $(80 \%)$ may represent a population of neurons formed during the peak of neurogenesis (E18-E19) that have just reached the pyramidal layer after sojourning $3 \mathrm{~d}$ in the intermediate zone (Altman and Bayer, 1990); synaptically active neurons are more developed and may have been generated at an earlier stage. (2) As in developing neocortical pyramidal cells (Marin-Padilla, 1992), the axon develops before the dendrites because the neurons have extended axons in stratum oriens and alveus, including cells that have no dendrites; and (3) the apical dendrite develops before the basilar dendrite.

\section{The sequential participation of GABA and glutamate in synaptic transmission}

The earlier establishment of GABAergic synapses on the apical dendrites of pyramidal neurons is in keeping with the distribution of synapsin-synaptophysin and GAD-positive terminals that are present in the stratum radiatum but not in the stratum pyramidale (Rozenberg et al., 1989; Dupuy and Houser, 1996). These fibers may originate either from GABAergic-positive neurons localized in the stratum radiatum (Super et al., 1998) or in other layers (Gaiarsa et al., 1995). In fact, morphological reconstructions suggest that at birth GABA-positive neurons are highly arborized with axonal arbors extending to dendritic layers (Gaiarsa et al., 1995). This is likely a consequence of their earlier generation (between E10 and E12) (Soriano et al., 1989; Super et al., 1998). The establishment of synapses only in neurons that have at least a small apical dendrite suggest that GABAergic fibers that are present in the stratum radiatum before birth (Rozenberg et al.,
1989; Dupuy and Houser, 1996) must await the development of pyramidal cells to establish synaptic contacts. Interestingly, the presence of a single branch of the apical dendrite in the stratum radiatum is sufficient for the formation of functional GABAergic synapses, suggesting that the transport, clustering, and synaptic expression of $\mathrm{GABA}_{\mathrm{A}}$ Rs occurs rapidly after the contact between the GABA terminals and the apical dendrite has been established.

As for GABAergic fibers, the glutamatergic inputs are present before the arrival of the dendrites in the molecular layers (Super and Soriano, 1994; Super et al., 1998). However, a different situation prevails for the formation of functional commissuralassociational synapses. The crucial factor appears to be the presence of the dendrite in the lacunosum moleculare independently of the total dendritic length in stratum radiatum (from 31 to 743 $\mu \mathrm{m})$. Although the molecular mechanisms have not been identified, the following observations deserve emphasis: (1) in cultures of developing hippocampal neurons, synaptic contacts are established before the synaptic localization of glutamate receptors, which occurs once dendritic spines are formed (Rao et al., 1998). This raises the possibility that glutamatergic synapses are present in GABA-only neurons, but AMPARs are extrasynaptically located. However, in keeping with a previous study (Durand et al., 1996), our results show that dendritic spines are not required for the development of functional glutamatergic synaptic transmission. Indeed, spines were either absent or their density was extremely low in our neuronal population, and there was no correlation between the presence of spines and the type of synaptic responses evoked; (2) Soriano and coworkers have recently suggested that glutamatergic synapses are first established on GABAergic pioneer neurons (Super et al., 1998). They propose that synaptic contacts between glutamatergic axons and pyramidal neurons occur only after the death of these pioneer GABAergic neurons. Although this possibility cannot be ex- 

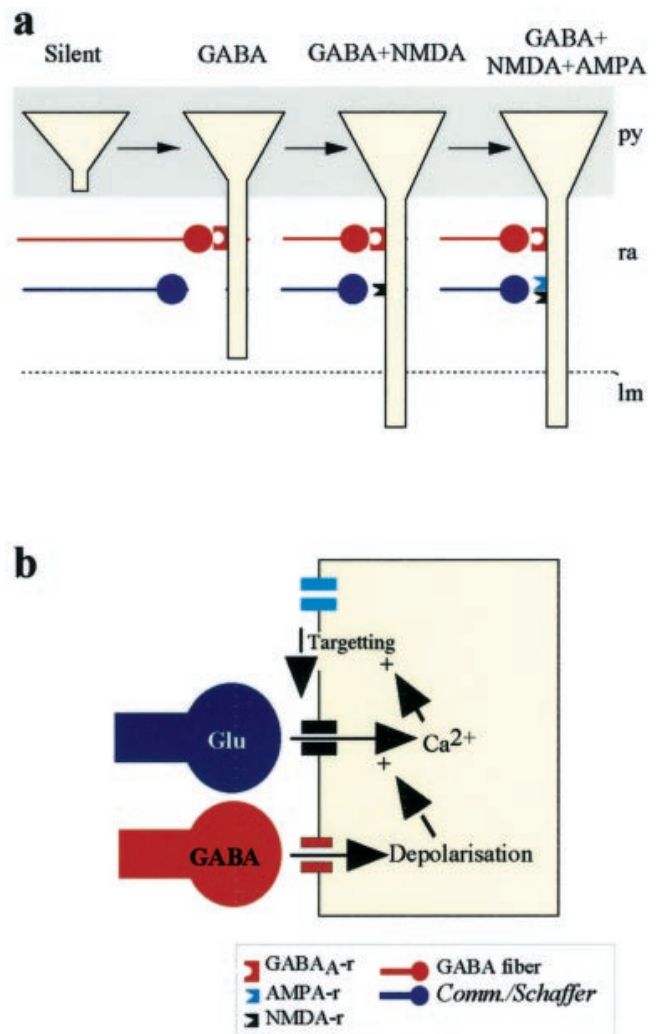

Figure 9. Schematic diagram to depict the CA1 network in P0 hippocampal rats. $a$, Three different stages of maturation of pyramidal cell are observed at P0. To simplify this scheme, basilar dendrites and fibers in stratum oriens are not represented. Silent pyramidal cells have an anlage of apical dendrite restricted to the stratum pyramidale and are not contacted by synaptic inputs, although they have functional $\mathrm{GABA}_{\mathrm{A}}$ and glutamate receptors (not shown). Pyramidal cells that have an apical dendrite in the stratum radiatum are contacted by GABAergic fibers. Functional Schaffer-commissural synapses are present only in cells that have apical dendrites in the stratum lacunosum moleculare. NMDARs are expressed at the synaptic site before AMPA receptors. $B$, Proposed model for the late participation of AMPA receptors to the synaptic transmission. The depolarization produced by GABA removes the voltagedependent $\mathrm{Mg}^{2+}$ block from NMDA receptors (Leinekugel et al., 1997). The resulting increase in $\left[\mathrm{Ca}^{2+}\right]_{i}$ promotes the synaptic expression of AMPA receptors that colocalize with NMDA receptors.

cluded, the abrupt formation of glutamatergic synapses on pyramidal neurons once their dendrite has penetrated the stratum lacunosum moleculare cannot be readily reconciled with this progressive program cell death; (3) our observations suggest an inductive role of the lacunosum moleculare in the maturation of glutamatergic contacts. It is possible that factors are secreted in this layer and trigger the formation of functional glutamatergic synapses either in the stratum radiatum and/or in the lacunosum moleculare. This signal could belong to the family of neurotrophins because: (1) BDNF mRNA is expressed in the entorhinal hippocampal system at an early stage of development (Martinez et al., 1998), and it has been suggested that perforant path could release neurotrophins (Kossel et al., 1997); (2) TrkB and TrkC mRNAs are detected from embryonic stages in the hippocampus (Martinez et al., 1998); (3) mice lacking TrkB and TrkC receptors have a reduced number of perforant path and commissuralassociational synaptic contacts on pyramidal neurons (Martinez et al., 1998); (4) neurotrophins accelerate the formation of excitatory connections (Vicario-Abejon et al., 1998). However, an al- ternative possibility is that the lacunosum moleculare has no permissive effect per se, but the presence of the apical dendrite in this layer only reflects more developed pyramidal neurons. In this scenario, the signal required for the formation of functional commissural-associational synapses on pyramidal neurons is determined by their age.

Whatever the mechanisms, our observations suggest that formation of glutamatergic synapses requires a set of conditions that differ from those required for the formation of GABAergic synapses.

\section{Glutamate-silent cells precede glutamate-active cells}

Physiological and morphological studies suggest an earlier participation of NMDARs than AMPARs to synaptic transmission (Ben-Ari et al., 1989; Durand et al., 1996; Wu et al., 1996; Isaac et al., 1997; Hsia et al., 1998; Liao et al., 1999; Petralia et al., 1999; see also Rao et al., 1998). In keeping with these studies, we also found a few neurons with PSCs mediated only by NMDARs even in response to strong electrical stimuli and did not observe the converse: PSCs mediated by AMPA but not NMDARs. There are therefore silent neurons and not only silent synapses, as in these neurons all glutamatergic synapses will not be active at resting membrane potential, provided that $\mathrm{GABA}_{\mathrm{A}}$ receptors are blocked. Our observation that the vast majority of glutamatergic PSCs are mediated by both NMDA and AMPARs and very few (3 of 119 cells) by NMDARs contrast with another study in which pure NMDA synapses predominate at an early stage of development in the CA1 region of the hippocampus (Durand et al., 1996). The simplest explanation is that these authors used minimal stimulations to determine the properties of few and possibly single synaptic PSCs. In contrast, in the present study, we have used maximal stimuli because our aims were to determine the ensemble PSCs of developing neurons. Therefore, our results do not provide indications on the percentage of pure NMDA synapses or mixed NMDA plus AMPA synapses on individual neurons. In fact, determining the exact percentage may be a difficult task in view of the apparent rapid conversion by neuronal discharge of silent synapses to active ones

The synaptic expression of AMPARs is modulated by activity involving the activation of NMDARs and an increase in $\left[\mathrm{Ca}^{2+}\right]_{\mathrm{i}}$ (Malenka and Nicoll, 1997). Because GABA is depolarizing and removes the voltage-dependent $\mathrm{Mg}^{2+}$ block from NMDA channels (Leinekugel et al., 1997) and GABA and NMDARs participate in PSCs before AMPARs (present data), we suggest that the synergist activation of GABA and NMDARs strongly contributes to the maturation of glutamatergic synapses (Fig. 9b).

In conclusion, the coexistence of these different steps of maturation in $\mathrm{P} 0$ hippocampal slices provides a rare opportunity to study in vivo factors that may control the morphological development of pyramidal cells, synaptic expression of receptors, formation of functional synapses, and thus understand how the hippocampal circuit develops.

\section{REFERENCES}

Altman J, Bayer SA (1990) Prolonged sojourn of developing pyramidal cells in the intermediate zone of the hippocampus and their settling in the stratum pyramidale. J Comp Neurol 301:343-364.

Bayer SA (1980) Development of the hippocampal region in the rat. I. Neurogenesis examined with $\left[{ }^{3} \mathrm{H}\right]$ thymidine autoradiography. J Comp Neurol 190:87-114.

Ben-Ari Y, Cherubini E, Corradetti R, Gaiarsa JL (1989) Giant synaptic potentials in immature rat CA3 hippocampal neurones. J Physiol (Lond) 416:303-325.

Ben-Ari Y, Khazipov R, Leinekugel X, Caillard O, Gaiarsa JL (1997) 
$\mathrm{GABA}_{\mathrm{A}}$, NMDA and AMPA receptors: a developmentally regulated "menage a trois". Trends Neurosci 20:523-529.

Blanton MG, Kriegstein AR (1992) Properties of amino acid neurotransmitter receptors of embryonic cortical neurons when activated by exogenous and endogenous agonists. J Neurophysiol 67:1185-1200.

Chen G, Trombley PQ, Van Den Pol AN (1995) GABA receptors precede glutamate receptors in hypothalamic development; differential regulation by astrocytes. J Neurophysiol 74:1473-1483.

Cherubini E, Gaiarsa JL, Ben-Ari Y (1991) GABA: an excitatory transmitter in early postnatal life. Trends Neurosci 14:515-519.

Dupuy ST, Houser CR (1996) Prominent expression of two forms of glutamate decarboxylase in the embryonic and early postnatal rat hippocampal formation. J Neurosci 16:6919-6932.

Durand GM, Kovalchuk Y, Konnerth A (1996) Long-term potentiation and functional synapse induction in developing hippocampus. Nature 381:71-75.

Essrich C, Lorez M, Benson JA, Fritschy JM, Lüscher B (1998) Postsynaptic clustering of major $\mathrm{GABA}_{\mathrm{A}}$ receptor subtypes requires the gamma 2 subunit and gephryn. Nat Neurosci 1:563-571.

Gaiarsa JL, McLean H, Congar P, Leinekugel X, Khazipov R, Tseeb V, Ben-Ari Y (1995) Postnatal maturation of $\gamma$-aminobutyric acid A and B-mediated inhibition in the CA3 hippocampal region of the rat. J Neurobiol 26:339-349.

Garaschuk O, Hanse E, Konnerth A (1998) Developmental profile and synaptic origin of early network oscillations in the CA1 region of rat neonatal hippocampus. J Physiol (Lond) 507:219-236.

Hamill OP, Marty A, Neher E, Sakmann B (1981) Improved patchclamp techniques for high-resolution current recording from cell and cell-free membrane patches. Pflügers Arch 391:85-100.

Hosokawa Y, Sciancalepore M, Stratta F, Martina M, Cherubini E (1994) Developmental changes in spontaneous $\mathrm{GABA}_{\mathrm{A}}$-mediated synaptic events in rat hippocampal CA3 neurons. Eur J Neurosci 6:805-813.

Hsia AY, Malenka RC, Nicoll RA (1998) Development of excitatory circuitry in the hippocampus. J Neurophysiol 79:2013-2024.

Isaac JT, Crair MC, Nicoll RA, Malenka RC (1997) Silent synapses during development of thalamocortical inputs. Neuron 18:269-280.

Khazipov R, Leinekugel X, Khalilov I, Gaiarsa JL, Ben-Ari Y (1997) Synchronization of GABAergic interneuronal network in CA3 subfield of neonatal rat hippocampal slices. J Physiol (Lond) 498:763-772.

Killisch I, Dotti CG, Laurie DJ, Lüddens H, Seeburg PH (1991) Expression patterns of $\mathrm{GABA}_{\mathrm{A}}$ receptor subtypes in developing hippocampal neurons. Neuron 7:927-936.

Kirov SA, Harris KM (1999) Slices have more synapses than perfusionfixed hippocampus from both young and mature rats. J Neurosci 19:2876-2886.

Kossel AH, Williams CV, Schweizer M, Kater SB (1997) Afferent innervation influences the development of dendritic branches and spines via both activity-dependent and non-activity-dependent mechanisms. J Neurosci 17:6314-6324.

Leinekugel X, Medina I, Khalilov I, Ben-Ari Y, Khazipov R (1997) $\mathrm{Ca}^{2+}$ oscillations mediated by the synergistic excitatory actions of $\mathrm{GABA}_{\mathrm{A}}$ and NMDA receptors in the neonatal hippocampus. Neuron 18:243-255.

Liao D, Zhang X, O’Brien R, Ehlers MD, Huganir RL (1999) Regulation of morphological postsynaptic silent synapses in developing hippocampal neurons. Nature 2:37-43.

Liu YB, Lio PA, Pasternak JF, Trommer BL (1996) Developmental changes in membrane properties and postsynaptic currents of granule cells in rat dentate gyrus. J Neurophysiol 76:1074-1088.
LoTurco JJ, Owens DF, Heath MJ, Davis MB, Kriegstein AR (1995) GABA and glutamate depolarize cortical progenitor cells and inhibit DNA synthesis. Neuron 15:1287-1298.

Malenka RC, Nicoll RA (1997) Silent synapses speak up. Neuron 19:473-476.

Marin-Padilla M (1992) Ontogenesis of the pyramidal cell of the mammalian neocortex and developmental cytoarchitectonics: a unifying theory. J Comp Neurol 321:223-240.

Martinez A, Alcantara S, Borrell V, Del RJ, Blasi J, Otal R, Campos N, Boronat A, Barbacid M, Silos-Santiago I, Soriano E (1998) TrkB and TrkC signaling are required for maturation and synaptogenesis of hippocampal connections. J Neurosci 18:7336-7350.

Owens DF, Boyce LH, Davis MB, Kriegstein AR (1996) Excitatory GABA responses in embryonic and neonatal cortical slices demonstrated by gramicidin perforated-patch recordings and calcium imaging. J Neurosci 16:6414-6423.

Petralia RS, Esteban JA, Wang YX, Partridge JG, Zhao HM, Wenthold RJ, Malinow R (1999) Selective acquisition of AMPA receptors over postnatal development suggests a molecular basis for silent synapses. Nature 2:31-36.

Rajan I, Cline HT (1998) Glutamate receptor activity is required for normal development of tectal cell dendrites in vivo. J Neurosci 18:7836-7846.

Rao A, Kim E, Sheng M, Craig AM (1998) Heterogeneity in the molecular composition of excitatory postsynaptic sites during development of hippocampal neurons in culture. J Neurosci 18:1217-1229.

Rivera C, Voipio J, Payne JA, Ruusuvuori E, Lahtinen H, Lamsa K, Pirvola U, Saarma M, Kaila K (1999) The $\mathrm{K}^{+} / \mathrm{Cl}^{-}$co-transporter $\mathrm{KCC} 2$ renders GABA hyperpolarizing during neuronal maturation. Nature 397:251-255.

Rozenberg F, Robain O, Jardin L, Ben-Ari Y (1989) Distribution of GABAergic neurons in late fetal and early postnatal rat hippocampus. Dev Brain Res 50:177-187.

Serafini R, Ma W, Maric D, Maric I, Lahjouji F, Sieghart W, Barker J (1998) Initially expressed early rat embryonic $\mathrm{GABA}_{\mathrm{A}}$ receptor $\mathrm{Cl}^{-}$ ion channels exhibit heterogenous channel properties. Eur J Neurosci 10:1771-1783.

Soriano E, Cobas A, Fairen A (1989) Neurogenesis of glutamic acid decarboxylase immunoreactive cells in the hippocampus of the mouse. I: Regio superior and regio inferior. J Comp Neurol 281:586-602.

Super H, Soriano E (1994) The organization of the embryonic and early postnatal murine hippocampus. II. Development of entorhinal, commissural, and septal connections studied with the lipophilic tracer DiI. J Comp Neurol 344:101-120.

Super H, Martinez A, Del RJ, Soriano E (1998) Involvement of distinct pioneer neurons in the formation of layer-specific connections in the hippocampus. J Neurosci 18:4616-4626.

Vicario-Abejon C, Collin C, McKay RDG, Segal M (1998) Neurotrophins induce formation of functional excitatory and inhibitory synapses between cultured hippocampal neurons. J Neurosci 18:7256-7271.

Walton MK, Schaffner AE, Barker JL (1993) Sodium channels, GABA receptors, and glutamate receptors develop sequentially on embryonic rat spinal cord cells. J Neurosci 2068-2084.

Wu G, Malinow R, Cline HT (1996) Maturation of a central glutamatergic synapse. Science 274:972-976.

Ziv N, Smith SJ (1996) Evidence for a role of dendritic filopodia in synaptogenesis and spine formation. Neuron 17:91-102. 